Published in final edited form as:

Am J Physiol Cell Physiol. 2008 April ; 294(4): C869-C878.

\title{
INTERMEDIATE FILAMENTS IN SMOOTH MUSCLE
}

\author{
Dale D. Tang \\ The Center for Cardiovascular Sciences, Albany Medical College, 47 New Scotland Avenue, MC8, \\ Albany, New York 12208
}

\begin{abstract}
The intermediate filament (IF) network is one of the three cytoskeletal systems in smooth muscle. The type III IF proteins vimentin and desmin are major constituents of the network in smooth muscle cells and tissues. Lack of vimentin or desmin impairs contractile ability of various smooth muscle preparations, implying their important role for smooth muscle force development. The IF framework has long been viewed as a fixed cytostructure that solely provides mechanical integrity for the cell. However, recent studies suggest that the IF cytoskeleton is dynamic in mammalian cells in response to various external stimulation. In this review, the structure and biological properties of IF proteins in smooth muscle are summarized. The role of IF proteins in the modulation of smooth muscle force development and redistribution/translocation of signaling partners (such as p130 Crk-associated substrate, CAS) is depicted. This review also summarizes our latest understanding on how the IF network may be regulated in smooth muscle.
\end{abstract}

\section{Keywords}

Cytoskeleton; force development; vimentin; and desmin

\begin{abstract}
The intermediate filament (IF) network is one of the three cytoskeletal systems in the cell. IFs are widely distributed from the plasma membrane to the nucleus, providing mechanical and structural integrity for the cell $(14 ; 38 ; 63)$. In the cell, assembled IFs are resistant to the extraction with detergents and high salt solution, under which the other two cytoskeletal systems (actin filaments and microtubules) are soluble $(38 ; 100)$. Therefore, they have long been viewed as a fixed cytoarchitecture that solely protects cells against various mechanical stresses. However, recent studies from several research groups demonstrate that IFs undergo spatial reorganization in a variety of cell types in response to stimulation with physiologic signals. The dynamic IFs play an essential role in regulating various cellular functions including signal transduction; tension development; cell division and migration; and gene expression $(14 ; 38 ; 63)$.
\end{abstract}

The smooth muscle cell is a key component of the cardiovascular, respiratory, digestive, and reproductive systems. Smooth muscles are unique in that in response to external stimulation, they are able to adjust their contraction/relaxation status by reorganizing the actin cytoskeleton and the IF network $(27 ; 28 ; 36 ; 37 ; 63 ; 67 ; 103 ; 113 ; 114)$. In contrast, the cytoskeletal systems of striated muscles are relatively stable $(3 ; 54 ; 95 ; 96)$.

In this review, the molecular structure, and biological properties of IF proteins in smooth muscle will be summarized. Evidence regarding the role and regulation of the IF system in smooth muscle signaling associated with force development will be also presented and discussed.

Correspondence: Dale D. Tang, The Center for Cardiovascular Sciences, Albany Medical College, 47 New Scotland Avenue, MC-8, Albany, NY 12208, Tel: (518)-262-6416; Fax: (518)-262-8101, E-mail: tangd@mail.amc.edu. 


\section{STRUCTURE AND PROPERTIES OF INTERMEDIATE FILAMENT PROTEINS IN SMOOTH MUSCLE}

\section{Type III IF proteins vimentin and desmin are major components of the IF networks in smooth muscle}

Thus far, at least 65 proteins have been found to constitute IF frameworks in different cell types whereas relatively few proteins make up actin microfilaments and microtubules. The genes encoding IF proteins are considered to be one of the largest families of genes in human genome $(44 ; 129)$. The expression of IF proteins is cell- and tissue-type specific, providing each cell/ tissue type with a relatively unique marker. The IF proteins can be divided into six major types based on sequence similarities, immunological, and biochemical properties (Table 1).

Type III IF proteins vimentin and desmin are major constituents of the IF networks in smooth muscle. Smooth muscle from the respiratory, digestive, and urogenital systems contain both desmin and vimentin $(23 ; 24 ; 53 ; 84 ; 113 ; 115)$. The protein ratio of vimentin to desmin is $6: 1$ in airway smooth muscle tissues $(113 ; 114)$. However, vascular smooth muscle cells mainly express vimentin instead of desmin. Vimentin is widely distributed in various blood vessels ranging from elastic arteries to microarteries while desmin is not or very little detected in large arteries such as aorta. Desmin is mainly present in microarteries $(23 ; 24 ; 84)$.

Vimentin forms a filamentous structure extending from the membrane to the nucleus, whereas desmin is primarily localized in the periphery of airway smooth muscle cells. Vimentin filaments connect to the membrane at the desmosome, an intercellular junction. At the desmosome, the cytoplasmic portions of transmembrance desmocollin and desmoglein connect with vimentin filaments via desmosomal proteins such as plakoglobin. The extracellular domains of desmocollin and desmoglein engage with their counterparts in adjacent cells to form the intercellular linkage. In addition, in the cytoplasm, vimentin filaments connect to dense bodies to which actin filaments also attach $(26 ; 63 ; 103 ; 113 ; 114)$.

The type VI IF protein synemin is found in striated muscle and smooth muscle $(4 ; 52 ; 73 ; 79$; 90). Synemin colocalizes with vimentin filaments and interacts with desmin, $\alpha$-actinin (a major component of Z-disks), dystrophin, and utrophin in striated muscle cells. Therefore, it may form heteropolymers with vimentin or desmin and link IFs to Z-disks of adjacent myofibrils or to the costamere, a sub-sarcolemma protein complex that align in register with Z-disks and physically connect to sarcomeres $(4 ; 5)$. The functional role of synemin in smooth muscle is not well understood. Another muscle associated type VI IF protein nestin may be associated with the development of myogenic tissues $(88 ; 110)$.

Intermediate filament-associated proteins (IFAPs) such as plectin and syncoulin have been found in striated muscle (Table 1). They have been implicated in connecting IFs to the plasma membrane, the outer nuclear membrane, and other cellular structures such as microtubules and actin filaments. The role of IFAPs in smooth muscle remains to be assessed.

\section{Structure and assembly of smooth muscle intermediate filament proteins}

Similar to other IF proteins, the molecular structure of vimentin and desmin is comprised of a central $\alpha$-helical rod domain flanked by non $\alpha$-helical N-terminal ("head") domains and Cterminal ("tail") domains. The central rod domain consists of Coil-1 domain including the subdomains $1 \mathrm{~A}$ and $1 \mathrm{~B}$ and Coil-2 domain containing the subdomains $2 \mathrm{~A}$ and $2 \mathrm{~B}$. These subdomains are separated by 3 linkers referred to as L1, L12 and L2. Amino acid sequences of the rod domain are conserved whereas sequences of head or tail domains are variable among different IF proteins $(41 ; 43 ; 64 ; 75 ; 80)$ (Fig. 1). 
Ultrastructural and immunostaining analysis of cells indicates that the central rod domains of IF proteins pair to a parallel coiled-coil dimer $(40 ; 41 ; 64)$. The subdomain $1 \mathrm{~A}$ is a single and amphipatic $\alpha$-helix with slight curvature, which may facilitate dimer formation (101). A pair of dimers associates laterally into an antiparallel tetramer. IF proteins lacking the head domain do not assemble into filaments (75). There is evidence that the tetramer, not the dimer, is the subunit for assembly of IF proteins $(22 ; 58 ; 97)$ (Fig. 1). Tetramers interact with one another through the intermolecular head-to-end association, forming $2-3 \mathrm{~nm}$ protofilaments, which pair each other into protofibrils. Four protofibrils form a single IF with $10-\mathrm{nm}$ in diameter.

Unlike actin filaments or microtubules, the assembled vimentin and/or desmin IFs appear to have no polarity, because the individual dimers are orientated along its axis in either direction $(42 ; 101)$. Furthermore, vimentin/desmin assembly does not require ATP or GTP whereas actin polymerization is ATP-dependent and microtubule formation is GTP-dependent $(38 ; 42 ; 101)$.

The head domains of IF proteins are exposed to the surface of IFs. The head domains are crucial for the assembly of IFs; vimentin mutants lacking the head domains are not able to form tetramers and full-length filaments $(41 ; 80)$. Several phosphorylation sites (Ser-38, Ser-56, and Ser-72) have been identified in the segment. In smooth muscle cells/tissues, Ser-56 is a major regulatory phosphorylation site on vimentin in response to contractile activation $(63,103$, 114). Phosphorylation on the head domains of IF proteins have been shown to mediate IF disassembly in many cell types including smooth muscle in response to external stimulation or during mitosis $(33 ; 61-63 ; 103 ; 114)$.

A portion of the tail domains of IF proteins is also believed to protrude from the backbone of IFs, facilitating interactions with other cellular molecules. However, the portions of the tail domains associated with inter-dimer interactions and IF width control are likely to be internally localized (not exposed to surface of the molecule) $(43 ; 80)$. In addition, there are several phosphorylation sites (Ser-418,Ser-429, Thr-456 and Ser-457) in the tail domains, which may participate in the regulation of IF disassembly/assembly during mitosis (22;30).

\section{Dynamic properties of intermediate filament proteins in smooth muscle cells}

In addition to their roles in maintaining mechanical integrity of the cell, IFs undergo spatial and biochemical changes in smooth muscle cells/tissues in response to external activation, which participates in the regulation of various cellular functions.

The vimentin network undergoes spatial rearrangement in smooth muscle cells upon contractile activation. Cultured tracheal smooth muscle cells are utilized to study the structural reorientation of the vimentin IF network because the high-resolution vimentin filament images can be obtained from these cells $(63 ; 103)$. In unstimulated smooth muscle cells, vimentin exhibits a curved filamentous structure with a random arrangement. Vimentin filaments becomes straight, and orientated along the long axis of cells 5 or 15 min after stimulation with 5-hydroxytryptamine (5-HT, serotonin). The numbers of cells with displaying the reorientated vimentin filaments are dramatically increased in response to 5 -HT activation $(63 ; 103)$. These results demonstrate that contractile stimulation of smooth muscle cells induces a spatial reorientation of vimentin filaments.

Spatial reorganization of the vimentin network has also been observed in various nonmuscle cells in response to external stimulation. In quiescent endothelial cells, vimentin filaments displayed a well-spread structure from the membrane to the nucleus. The vimentin IF framework shrank to the perinuclear region in response to stimulation with platelet-derived growth factor (111). Treatment with epidermal growth factor or the small GTPase Cdc42 induced similar vimentin filament reorganization in fibroblasts (71). Furthermore, vimentin or keratin filaments constantly undergo organizational changes in epithelial cells, fibroblasts, and 
endothelial cells these cells without exposure to chemical or mechanical stimulation (38;72; 125).

The partial disassembly of vimentin filaments (another indication of vimentin dynamics) occurs in smooth muscle cells and tissues in response to contractile activation. Studies from the fractionation assay suggest that $10 \%$ of total vimentin is in disassembled form in unstimulated smooth muscle cells whereas the disassembled vimentin increases to $20 \%$ of total vimentin during contractile activation of smooth muscle cells $(103 ; 114)$. Similar results have been observed in nonmuscle cells (such as chromaffin cells, human fibroblasts, endothelial cells, and BHK-21 cells) in response to external stimulation $(22 ; 71 ; 85 ; 97)$, suggesting that the partial disassembly of IFs upon external stimulation is a universal phenomenon in mammalian cells.

Disassembly and reassembly of the IF network may occur during mitosis of some cell types including BHK-21 cells, U251-cells, T-24 cells, COS-7 cells and pancreatic acinar cells (16; $62 ; 124)$. There is evidence that cytoplasmic IF proteins (vimentin, desmin, and keratin) display extensive networks in interphase, and become spot-like structures during the transition of late prophase to metaphase. The cytoplasmic IF proteins then reassemble to a well-distributed structure in postmitotic cells $(16 ; 49 ; 62 ; 124)$. Nuclear lamins form a protein meshwork (referred to as nuclear lamina) located near the inner nuclear membrane in nonmitotic cells. The lamin meshwork undergoes depolymerization between prophase and metaphase, leading to the disassembly of the nuclear lamina and envelope, which is important for DNA distribution to daughter cells. Lamin repolymerization occurs to reassemble the nuclear lamina after mitosis $(9 ; 31)$. Protein phosphorylation has been shown to modulate the dynamic change in the IF frameworks during the mitotic progression $(16 ; 69 ; 124)$. In addition, the dynamic change in IF frameworks may not occur evenly throughout the cell. In epithelial cells, fluorescent keratin polypeptides formed small particles near submembrane regions. These keratin particles gradually grew into short filaments, moving inward and fusing with other short filaments and integrating into the peripheral keratin network. Furthermore, results from fluorescence recovery after photobleaching suggested that de novo formation of keratin filaments occurred at the peripheral area (120-122). The localized keratin filament assembly may be modulated by the formation of focal adhesions because nascent keratin filament precursors are found in lamillipodia (cellular regions of elevated actin turnover) and, disruption of focal adhesions by talin short hairpin RNA leads to the depletion of keratin filaments (119). However, these studies are performed in nonmuscle cells. Much should be done to evaluate whether smooth muscle cells share similar mechanisms.

\section{FUNCTIONS OF INTERMEDIATE FILAMENT PROTEINS IN SMOOTH MUSCLE}

There may be three IF polymers in smooth muscle cells/tissues: vimentin homopolymers, desmin homopolymers and vimentin/desmin co-polymers. Studies from in vitro assembly experiments have shown that vimentin is able to form both homopolymers and co-polymers with desmin; desmin also can form both homopolymers and co-polymers with vimentin (2; $32 ; 63 ; 66 ; 117)$. Whether a smooth muscle cell contains homopolymers and/or co-polymers depends upon cell types (e.g., vascular or airway smooth muscle cells) and cell positioning in tissues (e.g., cells from elastic arteries or from resistance arteries). Immunostaining analysis has demonstrated that vimentin is detected in the majority of smooth muscle cell/tissue types. In contrast, desmin distribution varies depending on cell/tissue types $(23 ; 24 ; 84 ; 89)$. Another study shows that the amount of desmin is relatively high in muscular arteries from human whereas the amount of desmin is very low in elastic arteries (53). In bovine aorta, vimentin and desmin are not completely colocalized; the medial longitudinal smooth muscle layer is strongly stained with desmin antibody, but not with vimentin antibody. In contrast, cells interspersed between some longitudinal smooth muscle bundles are stained with vimentin 
antibody, but not desmin antibody (89). In addition, different subcellular regions may have different IF polymers. In airway smooth muscle cells, vimentin filaments are mainly located in the cytoplasm whereas desmin is distributed in the cell periphery $(63 ; 103 ; 113)$, indicating that the cytoplasm contains vimentin homopolymers and the cortical region contains desmin homopolymers and/or vimentin/desmin co-polymers.

\section{Intermediate filaments and smooth muscle contraction}

It is well recognized that smooth muscle contraction is regulated by myosin regulatory light chain phosphorylation, which in turn triggers crossbridge cycling and force development $(36 ; 55 ; 98)$. However, recent studies demonstrate that the cytoskeletal systems in smooth muscle participate in the cellular processes that coordinate active force development. In addition to the actin cytoskeleton, the IF network has recently emerged as an essential component for force development in smooth muscle $(3 ; 37 ; 63 ; 104 ; 108 ; 113 ; 114)$.

There is evidence that lack of the IF protein vimentin attenuates contractile responses of smooth muscle to mechanical and/or agonist stimulation. In vimentin knockout mice, flow-induced dilation in mesenteric resistance arteries was significantly attenuated in comparison to wild type mice, suggesting a role for vimentin in shear stress (flow)-induced response. Nevertheless, agonist-induced mechanical responses were not investigated in resistance arteries of the vimentin-I- mice (39). In canine tracheal smooth muscle tissues, treatment with antisense oligodeoxynucleotides selectively downregulats the expression of vimentin without influencing desmin content. Vimentin depletion by antisense suppresses contractile responses to acetylcholine without attenuating the increase in myosin regulatory light chain phosphorylation. These results suggest that the vimentin cytoskeleton is required for smooth muscle contraction and that the attenuated force development in vimentin-deficient smooth muscle is not attributed to the inhibition of myosin activation (113;114). Vimentin deficiency also impairs the contractile capacity of fibroblasts in a study (21), suggesting an essential role for vimentin in influencing mechanical properties of nonmuscle cells as well.

It is not surprising that the muscle-specific IF protein desmin is involved in smooth muscle force development. Normally, the expression of desmin is very low in large arteries such as aorta, whereas desmin content is relatively high in microarteries $(53 ; 115)$. In a study on desmin $-1-$ mice, passive and $\mathrm{KCl}$-mediated circumference-stress relations in microarteries were lower when compared with wild type mice (115). Phenylephrine-induced tone of mesenteric arteries was also lower in desmin-deficient mice than in wild type mice (65). It was also documented that active smooth muscle force from vas deferens, urinary bladder and portal vein preparations was inhibited in desmin-/- mice when compared to corresponding wild type mice (94).

Considerable information is available in terms of how the vimentin network system may influence contractile properties of smooth muscle. First, vimentin filaments connect with the membrane at desmosomes that are complex intercellular junctions specialized to provide strong but dynamic cell-cell adhesion in various cell types and tissues including smooth muscle (60; $68 ; 95 ; 113)$. In vimentin-deficient smooth muscle tissues, force development in response to contractile stimulation is attenuated. Moreover, the structure of desmosomes is disrupted in these smooth muscle tissues as evidenced by immunostaining of plakoglobin (a major component of desmosomes). Thus, vimentin IFs may mediate force development by linking to the intercellular apparatus and facilitating intercellular mechanical transduction $(60 ; 113)$.

Second, the vimentin network undergoes spatial reorganization in various cell types including smooth muscle cells $(63 ; 71 ; 103 ; 111 ; 114)$. Because the vimentin filaments connect to cytoplasmic dense bodies (to which actin filaments also attach) and to desmosomes, it is possible that the spatial reorientation of vimentin filaments may facilitate the reorganization of contractile elements and/or the linkage of IFs to desmosomes, which may be a part of the 
cellular processes that coordinate force development in smooth muscle $(36 ; 60 ; 63 ; 95 ; 103$; $113 ; 114)$.

Third, the partial disassembly of vimentin filaments occurs in smooth muscle cells and tissues in response to contractile stimulation $(63 ; 103 ; 114)$. Furthermore, the vimentin cytoskeleton is able to associate with p130 Crk-associated substrate (CAS) in smooth muscle. CAS is an adapter protein that has been recently found to participate in the regulation of smooth muscle contraction. CAS gets phosphorylated on tyrosine residues in response to contractile activation and CAS depletion attenuates actin polymerization and force development in smooth muscle (77;106). Contractile activation also triggers the dissociation of CAS from cytoskeletal vimentin resulting in the redistribution of CAS to the membrane $(63 ; 114)$. The membraneassociated translocation of CAS may facilitate cortical actin assembly and force development $(27 ; 28 ; 45 ; 63 ; 82 ; 104 ; 108 ; 114 ; 127 ; 128)$.

In addition, vimentin partial disassembly has been shown to affect structural rearrangement of the vimentin cytoskeleton in smooth muscle cells. Contractile stimulation of smooth muscle cells induces both vimentin disassembly and the spatial reorganization of vimentin filaments (e.g. filament straightness in stimulated cells versus curvature of filaments in unstimulated cells) $(63 ; 103)$. Expression of a non-phosphorylatable vimentin mutant S56A (alanine substitution at Ser-56) in smooth muscle cells inhibits vimentin disassembly and the spatial reorganization of vimentin filaments upon contractile activation $(63 ; 103)$. Thus, it is also possible that the partial depolymerization of vimentin IFs may influence force development through its spatial reorientation $(63 ; 103 ; 114)$.

Fourth, the IF framework has been proposed to interact with the actin cytoskeleton in some cell types, including macrophages, epithelial cells, and fibroblasts (17;34;35). Treatment of epithelial cells with cytochalasin $\mathrm{D}$ (actin polymerization inhibitor) disrupts the organization of the keratin IF network (34). Moreover, contractile activation of smooth muscle cells induces both actin polymerization and vimentin filament spatial reorientation, which are important in regulating active force development $(3 ; 15 ; 28 ; 63 ; 70 ; 103-106 ; 108 ; 113)$. Thus, the spatial reorganization of vimentin filaments might be secondary to actin dynamics or vice versa. However, disruption of actin stress fibers by cytochalasin D did not inhibit the reorganization of vimentin filaments in cultured smooth muscle cells and HeLa cells $(13 ; 103)$, suggesting that the spatial reorientation of vimentin filaments is not secondary to actin polymerization. More studies are needed to assess whether vimentin dynamics modulate actin polymerization in smooth muscle cells.

Fifth, the vimentin IF network and microtubules form closely associated parallel arrays that are distributed throughout the cytoplasm of fibroblasts. Treatment with the microtubule disruption agents nocodazole, colchicines or colcemid induced vimentin filament rearrangement $(14 ; 50)$. It is possible that the spatial reorientation and/or disassembly of vimentin filaments may affect microtubule stability that is related to smooth muscle contraction. However, in two separate studies, exposure to nocodazole slightly enhanced $\mathrm{KCl}-$ induced vascular smooth muscle contraction by increasing intracellular $\mathrm{Ca}^{2+}$, not by influencing mechanical stiffness $(81 ; 126)$.

There is evidence to indicate how desmin may influence smooth muscle contraction. In striated muscle, desmin filaments form a lattice that surrounds the sarcomere and stabilizes contractile units $(8 ; 36)$. Nevertheless, desmin is primarily localized near the periphery in differentiated airway smooth muscle cells compared to extensive distribution of vimentin filaments from the membrane to perinuclear regions (113). The observation suggests that desmin localized in the cell cortex may reinforce the linkage of vimentin filaments to the desmosomes that facilitate cell-cell mechanical transduction in smooth muscle (113). In addition, in vitro studies show 
that desmin filaments are disassembled after treatment with PAK or Rho kinase (78).

Furthermore, acetylcholine stimulation of tracheal smooth muscle induces desmin disassembly associated with the increase in force development (107). Thus, it is reasonable to propose that contractile stimulation may cause desmin filament reorganization, which may participate in the modulation of tension development.

\section{Intermediate filaments and redistribution of signaling partners}

One of the new and exciting findings in the research area is that the IF network harbors certain signaling molecules and is able to influence their spatial distribution in response to external stimulation, which has been believed to regulate smooth muscle functions $(63 ; 67 ; 93 ; 114)$.

The vimentin cytoskeleton regulates CAS redistribution-The adapter protein CAS is a major member of the CAS family of proteins, which have been thought to serve as docking sites for other proteins in integrin-mediated signaling transduction $(19 ; 114)$. Recent studies have shown that CAS is an important signaling molecule that participates in the regulation of smooth muscle contraction. CAS undergoes tyrosine phosphorylation in rat aortic smooth muscle tissues in response to stimulation with 5-HT receptor agonists and in cultured smooth muscle cells activated by angiotensin II $(77 ; 102)$. Furthermore, the downregulation of CAS in smooth muscle tissues depresses active force development by inhibiting actin dynamics, a cellular process that is important for contractile force development in smooth muscle $(15 ; 47$; 70;104-106;108).

Vimentin is able to bind to CAS in in vitro and in vivo studies. Far-western analysis shows that purified unphosphorylated vimentin protein interacts with CAS immobilized on the nitrocellulose membrane, suggesting the association of unphosphorylated vimentin with CAS in vitro. Phosphorylation of vimentin by PAK inhibits its association with CAS (114). Fractionation assay indicates that approximately $50 \%$ of total CAS is associated with cytoskeletal vimentin in smooth muscle cells and tissues $(63 ; 114)$.

There is evidence that contractile activation results in the dissociation of CAS from cytoskeletal vimentin and the redistribution of CAS in smooth muscle. Contractile activation leads to the decrease in the ratios of CAS/cytoskeletal vimentin in smooth muscle cells and tissues.

Moreover, the ratios of insoluble/soluble CAS are decreased in smooth muscle cells in response to 5-HT stimulation. These results suggest that CAS is dissociated from the vimentin cytoskeleton during contractile activation $(63 ; 114)$. Immunofluorescence microscopic analysis also reveals that CAS is distributed in the myoplasm of unstimulated cells freshly dissociated from tracheal smooth muscle tissues. CAS relocalizes to the cell periphery in response to acetylcholine activation (114). Because actin assembly in smooth muscle is believed to occur in the cortical region of cells $(45 ; 128)$, it is probable that CAS dissociated from the vimentin cytoskeleton may translocate to the cell border, facilitating cortical actin polymerization and force development in smooth muscle $(63 ; 108 ; 114)$.

The vimentin cytoskeleton regulates translocation of protein kinases- $\mathrm{Ca}^{2+}$ / calmodulin-dependent protein kinase II (CamKII) is a protein kinase that has been implicated in regulating smooth muscle contraction $(57 ; 67 ; 86)$. Contractile stimulation leads to the activation of CamKII as evidenced by its phosphorylation in stimulated arterial smooth muscle. Moreover, inhibition of CamKII by the inhibitor KN-93 attenuates contractile responses of arterial smooth muscle $(57 ; 86)$. The depletion of CamKII by antisense oligodeoxynucleotides also depresses active force development in arterial smooth muscle (57).

Vimentin filaments may modulate the redistribution of CamKII during contractile activation of smooth muscle cells. When differentiated arterial smooth muscle cells were left unstimulated, CamKII $\gamma$ G-2 (a novel isoform in smooth muscle cells) was found in a 
cytoskeletal scaffold coincident with vimentin filaments. Upon activation with $\mathrm{KCl}$ depolarization, CamKII $\gamma$ G-2 was released into cytosol and eventually targeted to membrane associated dense plaques. The unique transition of the kinase is proposed to participate in signaling transduction in differentiated smooth muscle cells (67). One possible mechanism is that the translocation of CamKII activates its kinase activity, which may stimulate mitogenactivated kinase (MAPK) that may in turn induce caldesmon phosphorylation and smooth muscle contraction $(29 ; 48 ; 57 ; 67 ; 74)$.

Rho kinase is an effector of the small GTPase Rho, which may be involved in the reorganization of actin filaments and myosin activation $(91 ; 98)$. Rho kinase was reported to associate with purified vimentin in in vitro biochemical studies. Immunofluorescence studies confirmed a colocalization of Rho kinase and filamentous vimentin in vivo. More interestingly, Rho kinase translocated to the periphery of fibroblasts and Hela cells upon the collapse of the vimentin IF network. Additionally, Rho kinase moved to the membrane from vimentin filaments in fibroblasts after serum deprivation (93). Future studies are needed to determine whether the vimentin-associated translocation of Rho kinase occurs in smooth muscle upon contractile stimulation. If so, the spatial redistribution of Rho kinase affected by the vimentin cytoskeleton may activate Rho kinase, which may phosphorylate and inhibit myosin phosphatase, and result in the increase in myosin light chain phosphorylation and force generation (98).

\section{REGULATION OF INTERMEDIATE FILAMENTS IN SMOOTH MUSCLE}

Protein phosphorylation has been demonstrated to be a key event that regulates the functional properties of the IF framework. In cultured smooth muscle cells, serotonin stimulation induces vimentin phosphorylation at Ser-56 that is associated with the partial disassembly and spatial reorientation of vimentin filaments $(63 ; 103)$. Similarly, acetylcholine activation initiates the vimentin phosphorylation and depolymerization in airway smooth muscle tissues (114).

PAK (p21-activated kinase) is an upstream regulator of the vimentin cytoskeleton in smooth muscle. There is evidence that PAK is activated in response to contractile stimulation and that PAK mediates vimentin phosphorylation in vitro and in vivo. Activation with 5-HT induces phosphorylation of PAK1 (a major isoform in smooth muscle) in cultured tracheal smooth muscle cells $(18 ; 63 ; 103)$. PAK1 gets phosphorylated in vascular smooth muscle cells in response to angiotensin II stimulation (123). Phosphorylation of PAK has been proposed to induce a conformational change resulting in activation of the kinase (51). In vitro studies show that PAK directly catalyzes vimentin phosphorylation $(33 ; 63 ; 103)$. In cultured tracheal smooth muscle cells, silencing of PAK attenuates vimentin phosphorylation at Ser-56 upon activation with 5-HT (103). Likewise, acetylcholine-induced vimentin phosphorylation at Ser-56 is depressed in PAK-deficient tracheal smooth muscle tissues (114).

With regard to the functional consequences of vimentin phosphorylation mediated by PAK, it has been shown that PAK may regulate vimentin disassembly and spatial reorientation through vimentin phosphorylation in smooth muscle cells. Vimentin phosphorylation is associated with its disassembly and spatial reorganization in smooth muscle cells and tissues during agonist activation. The inhibition of vimentin phosphorylation by downregulating PAK attenuates its disassembly and/or spatial reorientation in cells and tissues upon contractile activation (63; 103;114). In in vitro studies, treatment of wild type vimentin with PAK inhibits formation of vimentin filaments whereas the treatment of the mutant vimentin S56A (alanine substitution at Ser-56) with PAK does not inhibit its filament assembly (63). Moreover, the stimulation with serotonin no longer induces vimentin disassembly and spatial reorientation in cells expressing the vimentin mutant S56A compared to control cells (63). As described earlier, the structural reorganization and/or partial disassembly of the vimentin cytoskeleton is involved in smooth muscle force development and redistribution of signaling partners. Thus, PAK may 
modulate smooth muscle contraction by regulating vimentin phosphorylation, depolymerization and spatial reorganization $(63 ; 67 ; 103 ; 113 ; 114)$.

Phosphorylation of vimentin may reciprocally modulate the activation of its upstream regulator PAK. Agonist stimulation of smooth muscle cells induces PAK phosphorylation at Thr-423, or Ser-199/204, an indication of kinase activation (51;59;63;123). Nevertheless, PAK phosphorylation in response to agonist activation is diminished in cells expressing the mutant vimentin S56A, suggesting a role for vimentin phosphorylation in regulating PAK activation. As described earlier, CAS is able to dissociate from cytoskeletal vimentin under agonist activation. Moreover, CAS may regulate PAK activity via a protein complex containing CrkII, paxillin, p95PKL (paxillin kinase linker), PIX (PAK-interacting exchange factor) and PAK (109). Thus, it is possible that the increase in soluble CAS mediated by vimentin phosphorylation during agonist stimulation may facilitate the formation of the multiprotein complex, which may eventually render PAK in an active state during agonist stimulation $(10 ; 63 ; 109)$ (Fig. 2).

It has been shown that desmin gets phosphorylated in an in vitro biochemical study (78). There is evidence that desmin phosphorylation occurs in cells/tissues in response to biological signals/ treatment. In a Triton-skinned smooth muscle preparation, the introduction of PAK induced desmin phosphorylation at constant intracellular $\mathrm{Ca}^{2+}$. The $\mathrm{Ca}^{2+}$-independent desmin phosphorylation was implicated in the modulation of smooth muscle contraction (112). Moreover, desmin phosphorylation is associated with its disassembly in smooth muscle tissues in response to contractile activation (107). It is possible that desmin phosphorylation may influence the temporal and spatial array of structural proteins and/or signaling partners in smooth muscle in response to contractile stimulation.

\section{Summary and Conclusions}

Exploring the functions and regulation of IF proteins in smooth muscle is a new development in muscle physiology. Studies on knockout mice and smooth muscle tissues suggest that both vimentin and desmin are required for force development. Contractile activation induces the partial disassembly of vimentin and/or desmin filaments, which may modulate force development through the redistribution of signaling molecules (e.g., CAS and CamKII). Elucidating how IF proteins affect the translocation of signaling molecules will be an important direction in this research area. Vimentin filaments undergo spatial rearrangement in smooth muscle cells upon contractile activation, which may be a part of cytoskeletal reorganization processes that modulate smooth muscle contraction. The dynamic feature of IFs is regulated by the site-specific phosphorylation of IF proteins. PAK is a major kinase responsible for IF protein phosphorylation in smooth muscle. Conversely, vimentin phosphorylation may influence PAK activation via CAS release from cytoskeletal vimentin. There is not much information on how contractile stimulation (mainly receptor activation) may activate PAK; filling this knowledge gap will enhance our understanding of the signaling cascades that regulate IF networks in smooth muscle.

\section{Acknowledgements}

The author would like to acknowledge the support of a grant from the National Heart, Lung and Blood Institute (HL-75388.

\section{References}

1. Balogh J, Li Z, Paulin D, Arner A. Desmin filaments influence myofilament spacing and lateral compliance of slow skeletal muscle fibers. Biophys J 2005;88:1156-1165. [PubMed: 15542565] 
2. Bar H, Mucke N, Ringler P, Muller SA, Kreplak L, Katus HA, Aebi U, Herrmann H. Impact of disease mutations on the desmin filament assembly process. J Mol Biol 2006;360:1031-1042. [PubMed: 16828798]

3. Barany M, Barron JT, Gu L, Barany K. Exchange of the actin-bound nucleotide in intact arterial smooth muscle. J Biol Chem 2001;276:48398-48403. [PubMed: 11602582]

4. Bellin RM, Sernett SW, Becker B, Ip W, Huiatt TW, Robson RM. Molecular characteristics and interactions of the intermediate filament protein synemin. Interactions with alpha-actinin may anchor synemin-containing heterofilaments. J Biol Chem 1999;274:29493-29499. [PubMed: 10506213]

5. Bhosle RC, Michele DE, Campbell KP, Li Z, Robson RM. Interactions of intermediate filament protein synemin with dystrophin and utrophin. Biochem Biophys Res Commun 2006;346:768-777. [PubMed: 16777071]

6. Blake DJ, Martin-Rendon E. Intermediate filaments and the function of the dystrophin-protein complex. Trends Cardiovasc Med 2002;12:224-228. [PubMed: 12161077]

7. Blake DJ, Martin-Rendon E. Intermediate filaments and the function of the dystrophin-protein complex. Trends Cardiovasc Med 2002;12:224-228. [PubMed: 12161077]

8. Boriek AM, Capetanaki Y, Hwang W, Officer T, Badshah M, Rodarte J, Tidball JG. Desmin integrates the three-dimensional mechanical properties of muscles. Am J Physiol Cell Physiol 2001;280:C46C52. [PubMed: 11121375]

9. Bridger JM, Foeger N, Kill IR, Herrmann H. The nuclear lamina. Both a structural framework and a platform for genome organization. FEBS J 2007;274:1354-1361. [PubMed: 17489093]

10. Brown MC, Turner CE. Paxillin: adapting to change. Physiol Rev 2004;84:1315-1339. [PubMed: 15383653]

11. Brown SC, Torelli S, Ugo I, De BF, Howman EV, Poon E, Britton J, Davies KE, Muntoni F. Syncoilin upregulation in muscle of patients with neuromuscular disease. Muscle Nerve 2005;32:715-725. [PubMed: 16124004]

12. Capetanaki Y, Milner DJ. Desmin cytoskeleton in muscle integrity and function. Subcell Biochem 1998;31:463-495. [PubMed: 9932503]

13. Chan W, Kozma R, Yasui Y, Inagaki M, Leung T, Manser E, Lim L. Vimentin intermediate filament reorganization by Cdc42: involvement of PAK and p70 S6 kinase. Eur J Cell Biol 2002;81:692-701. [PubMed: 12553669]

14. Chang L, Goldman RD. Intermediate filaments mediate cytoskeletal crosstalk. Nat Rev Mol Cell Biol 2004;5:601-613. [PubMed: 15366704]

15. Chen X, Pavlish K, Zhang HY, Benoit JN. Effects of chronic portal hypertension on agonist-induced actin polymerization in small mesenteric arteries. Am J Physiol Heart Circ Physiol 2006;290:H1915H1921. [PubMed: 16339838]

16. Chou YH, Rosevear E, Goldman RD. Phosphorylation and disassembly of intermediate filaments in mitotic cells. Proc Natl Acad Sci U S A 1989;86:1885-1889. [PubMed: 2648386]

17. Correia I, Chu D, Chou YH, Goldman RD, Matsudaira P. Integrating the actin and vimentin cytoskeletons. Adhesion-dependent formation of fimbrin-vimentin complexes in macrophages. J Cell Biol 1999;146:831-842. [PubMed: 10459017]

18. Dechert MA, Holder JM, Gerthoffer WT. p21-activated kinase 1 participates in tracheal smooth muscle cell migration by signaling to p38 Mapk. Am J Physiol Cell Physiol 2001;281:C123-C132. [PubMed: 11401834]

19. Defilippi P, Di SP, Cabodi S. p130Cas: a versatile scaffold in signaling networks. Trends Cell Biol 2006;16:257-263. [PubMed: 16581250]

20. Djabali K. Cytoskeletal proteins connecting intermediate filaments to cytoplasmic and nuclear periphery. Histol Histopathol 1999;14:501-509. [PubMed: 10212812]

21. Eckes B, Dogic D, Colucci-Guyon E, Wang N, Maniotis A, Ingber D, Merckling A, Langa F, Aumailley M, Delouvee A, Koteliansky V, Babinet C, Krieg T. Impaired mechanical stability, migration and contractile capacity in vimentin-deficient fibroblasts. J Cell Sci 1998;111:1897-1907. [PubMed: 9625752]

22. Eriksson JE, He T, Trejo-Skalli AV, Harmala-Brasken AS, Hellman J, Chou YH, Goldman RD. Specific in vivo phosphorylation sites determine the assembly dynamics of vimentin intermediate filaments. J Cell Sci 2004;117:919-932. [PubMed: 14762106] 
23. Frank ED, Warren L. Aortic smooth muscle cells contain vimentin instead of desmin. Proc Natl Acad Sci U S A 1981;78:3020-3024. [PubMed: 7019916]

24. Gabbiani G, Schmid E, Winter S, Chaponnier C, de CC, Vandekerckhove J, Weber K, Franke WW. Vascular smooth muscle cells differ from other smooth muscle cells: predominance of vimentin filaments and a specific alpha-type actin. Proc Natl Acad Sci U S A 1981;78:298-302. [PubMed: 7017714]

25. Gao Y, Sztul E. A novel interaction of the Golgi complex with the vimentin intermediate filament cytoskeleton. J Cell Biol 2001;152:877-894. [PubMed: 11238446]

26. Garrod DR, Merritt AJ, Nie Z. Desmosomal adhesion: structural basis, molecular mechanism and regulation. Mol Membr Biol 2002;19:81-94. [PubMed: 12126234]

27. Gerthoffer WT. Actin cytoskeletal dynamics in smooth muscle contraction. Can J Physiol Pharmacol 2005;83:851-856. [PubMed: 16333356]

28. Gerthoffer WT, Gunst SJ. Invited review: focal adhesion and small heat shock proteins in the regulation of actin remodeling and contractility in smooth muscle. J Appl Physiol 2001;91:963-972. [PubMed: 11457815]

29. Gerthoffer WT, Yamboliev IA, Shearer M, Pohl J, Haynes R, Dang S, Sato K, Sellers JR. Activation of MAP kinases and phosphorylation of caldesmon in canine colonic smooth muscle. J Physiol 1996;495:597-609. [PubMed: 8887769]

30. Goldman RD, Chou YH, Prahlad V, Yoon M. Intermediate filaments: dynamic processes regulating their assembly, motility, and interactions with other cytoskeletal systems. FASEB Journal 1999;13 (Suppl 2):S261-S265. [PubMed: 10619140]

31. Goldman RD, Gruenbaum Y, Moir RD, Shumaker DK, Spann TP. Nuclear lamins: building blocks of nuclear architecture. Genes Dev 2002;16:533-547. [PubMed: 11877373]

32. Goto H, Kosako H, Tanabe K, Yanagida M, Sakurai M, Amano M, Kaibuchi K, Inagaki M. Phosphorylation of vimentin by Rho-associated kinase at a unique amino- terminal site that is specifically phosphorylated during cytokinesis. J Biol Chem 1998;273:11728-11736. [PubMed: 9565595]

33. Goto H, Tanabe K, Manser E, Lim L, Yasui Y, Inagaki M. Phosphorylation and reorganization of vimentin by p21-activated kinase (PAK). Genes Cells 2002;7:91-97. [PubMed: 11895474]

34. Green KJ, Geiger B, Jones JC, Talian JC, Goldman RD. The relationship between intermediate filaments and microfilaments before and during the formation of desmosomes and adherens-type junctions in mouse epidermal keratinocytes. J Cell Biol 1987;104:1389-1402. [PubMed: 2437129]

35. Green KJ, Goldman RD. Evidence for an interaction between the cell surface and intermediate filaments in cultured fibroblasts. Cell Motil Cytoskeleton 1986;6:389-405. [PubMed: 3757071]

36. Gunst SJ, Tang DD. The contractile apparatus and mechanical properties of airway smooth muscle. Eur Respir J 2000;15:600-616. [PubMed: 10759460]

37. Gunst SJ, Tang DD, Opazo SA. Cytoskeletal remodeling of the airway smooth muscle cell: a mechanism for adaptation to mechanical forces in the lung. Respir Physiol Neurobiol 2003;137:151168. [PubMed: 14516723]

38. Helfand BT, Chang L, Goldman RD. Intermediate filaments are dynamic and motile elements of cellular architecture. J Cell Sci 2004;117:133-141. [PubMed: 14676269]

39. Henrion D, Terzi F, Matrougui K, Duriez M, Boulanger CM, Colucci-Guyon E, Babinet C, Briand P, Friedlander G, Poitevin P, Levy BI. Impaired flow-induced dilation in mesenteric resistance arteries from mice lacking vimentin. J Clin Invest 1997;100:2909-2914. [PubMed: 9389758]

40. Herrmann H, Aebi U. Intermediate filaments and their associates: multi-talented structural elements specifying cytoarchitecture and cytodynamics. Curr Opin Cell Biol 2000;12:79-90. [PubMed: 10679360]

41. Herrmann H, Aebi U. Intermediate filaments: molecular structure, assembly mechanism, and integration into functionally distinct intracellular Scaffolds. Annu Rev Biochem 2004;73:749-789. [PubMed: 15189158]

42. Herrmann H, Bar H, Kreplak L, Strelkov SV, Aebi U. Intermediate filaments: from cell architecture to nanomechanics. Nat Rev Mol Cell Biol. 2007 
43. Herrmann H, Haner M, Brettel M, Muller SA, Goldie KN, Fedtke B, Lustig A, Franke WW, Aebi U. Structure and assembly properties of the intermediate filament protein vimentin: the role of its head, rod and tail domains. J Mol Biol 1996;264:933-953. [PubMed: 9000622]

44. Hesse M, Magin TM, Weber K. Genes for intermediate filament proteins and the draft sequence of the human genome: novel keratin genes and a surprisingly high number of pseudogenes related to keratin genes 8 and 18. J Cell Sci 2001;114:2569-2575. [PubMed: 11683385]

45. Higgs HN, Pollard TD. Regulation of actin filament network formation through ARP2/3 complex: activation by a diverse array of proteins. Annu Rev Biochem 2001;70:649-676. [PubMed: 11395419]

46. Hijikata T, Murakami T, Ishikawa H, Yorifuji H. Plectin tethers desmin intermediate filaments onto subsarcolemmal dense plaques containing dystrophin and vinculin. Histochem Cell Biol 2003;119:109-123. [PubMed: 12610730]

47. Hirshman CA, Zhu D, Pertel T, Panettieri RA, Emala CW. Isoproterenol induces actin depolymerization in human airway smooth muscle cells via activation of an Src kinase and GS. Am J Physiol Lung Cell Mol Physiol 2005;288:L924-L931. [PubMed: 15821021]

48. Horowitz A, Menice CB, Laporte R, Morgan KG. Mechanisms of smooth muscle contraction. Physiol Rev 1996;76:967-1003. [PubMed: 8874491]

49. Inada H, Togashi H, Nakamura Y, Kaibuchi K, Nagata K, Inagaki M. Balance between activities of Rho kinase and type 1 protein phosphatase modulates turnover of phosphorylation and dynamics of desmin/vimentin filaments. J Biol Chem 1999;274:34932-34939. [PubMed: 10574968]

50. Ishikawa H, Bischoff R, Holtzer H. Mitosis and intermediate-sized filaments in developing skeletal muscle. J Cell Biol 1968;38:538-555. [PubMed: 5664223]

51. Jaffer ZM, Chernoff J. p21-activated kinases: three more join the Pak. Int J Biochem Cell Biol 2002;34:713-717. [PubMed: 11950587]

52. Jing R, Wilhelmsson U, Goodwill W, Li L, Pan Y, Pekny M, Skalli O. Synemin is expressed in reactive astrocytes in neurotrauma and interacts differentially with vimentin and GFAP intermediate filament networks. J Cell Sci 2007;120:1267-1277. [PubMed: 17356066]

53. Johansson B, Eriksson A, Virtanen I, Thornell LE. Intermediate filament proteins in adult human arteries. Anat Rec 1997;247:439-448. [PubMed: 9096782]

54. Jones KA, Perkins WJ, Lorenz RR, Prakash YS, Sieck GC, Warner DO. F-actin stabilization increases tension cost during contraction of permeabilized airway smooth muscle in dogs. J Physiol 1999;519 (Pt 2):527-538. [PubMed: 10457068]

55. Kamm KE, Stull JT. Regulation of smooth muscle contractile elements by second messengers. Annu Rev Physiol 1989;51:299-313. [PubMed: 2653184]

56. Ketema M, Wilhelmsen K, Kuikman I, Janssen H, Hodzic D, Sonnenberg A. Requirements for the localization of nesprin-3 at the nuclear envelope and its interaction with plectin. J Cell Sci 2007;120:3384-3394. [PubMed: 17881500]

57. Kim I, Je HD, Gallant C, Zhan Q, Riper DV, Badwey JA, Singer HA, Morgan KG. Ca2+-calmodulindependent protein kinase II-dependent activation of contractility in ferret aorta. J Physiol 2000;526 (Pt 2):367-374. [PubMed: 10896725]

58. Kirmse R, Portet S, Mucke N, Aebi U, Herrmann H, Langowski J. A quantitative kinetic model for the in vitro assembly of intermediate filaments from tetrameric vimentin. J Biol Chem 2007;282:18563-18572. [PubMed: 17403663]

59. Knaus UG, Bokoch GM. The p21Rac/Cdc42-activated kinases (PAKs). Int J Biochem Cell Biol 1998;30:857-862. [PubMed: 9744077]

60. Ko KS, McCulloch CA. Intercellular mechanotransduction: cellular circuits that coordinate tissue responses to mechanical loading. Biochem Biophys Res Commun 2001;285:1077-1083. [PubMed: 11478763]

61. Ku NO, Liao J, Omary MB. Phosphorylation of human keratin 18 serine 33 regulates binding to 14-3-3 proteins. EMBO J 1998;17:1892-1906. [PubMed: 9524113]

62. Ku NO, Michie S, Resurreccion EZ, Broome RL, Omary MB. Keratin binding to 14-3-3 proteins modulates keratin filaments and hepatocyte mitotic progression. Proc Natl Acad Sci U S A 2002;99:4373-4378. [PubMed: 11917136] 
63. Li QF, Spinelli AM, Wang R, Anfinogenova Y, Singer HA, Tang DD. Critical Role of Vimentin Phosphorylation at Ser-56 by p21-activated Kinase in Vimentin Cytoskeleton Signaling. J Biol Chem 2006;281:34716-34724. [PubMed: 16990256]

64. Lodish, H.; Berk, A.; Zipursky, SL.; Matsudaira, P.; Baltimore, D.; Darnell, J. Cell motility and shape II: Microtubules and intermediate filaments. In: Tenny, S., editor. Molecular Cell Biology. New York: W.H. Freeman and Company; 2000. p. 793-847.

65. Loufrani L, Matrougui K, Li Z, Levy BI, Lacolley P, Paulin D, Henrion D. Selective microvascular dysfunction in mice lacking the gene encoding for desmin. FASEB J 2002;16:117-119. [PubMed: 11729100]

66. Mabuchi K, Li B, Ip W, Tao T. Association of calponin with desmin intermediate filaments. J Biol Chem 1997;272:22662-22666. [PubMed: 9278424]

67. Marganski WA, Gangopadhyay SS, Je HD, Gallant C, Morgan KG. Targeting of a novel Ca2+/ calmodulin-dependent protein kinase II is essential for extracellular signal-regulated kinase-mediated signaling in differentiated smooth muscle cells. Circ Res 2005;97:541-549. [PubMed: 16109919]

68. Matsushita T, Oyamada M, Kurata H, Masuda S, Takahashi A, Emmoto T, Shiraishi I, Wada Y, Oka T, Takamatsu T. Formation of cell junctions between grafted and host cardiomyocytes at the border zone of rat myocardial infarction. Circulation 1999;100:II262-II268. [PubMed: 10567314]

69. Mattout A, Dechat T, Adam SA, Goldman RD, Gruenbaum Y. Nuclear lamins, diseases and aging. Curr Opin Cell Biol 2006;18:335-341. [PubMed: 16632339]

70. Meeks MK, Ripley ML, Jin Z, Rembold CM. Heat shock protein 20-mediated force suppression in forskolin-relaxed swine carotid artery. Am J Physiol Cell Physiol 2005;288:C633-C639. [PubMed: 15509660]

71. Meriane M, Mary S, Comunale F, Vignal E, Fort P, Gauthier-Rouviere C. Cdc42Hs and Rac1 GTPases induce the collapse of the vimentin intermediate filament network. J Biol Chem 2000;275:3304633052. [PubMed: 10900195]

72. Miller RK, Vikstrom K, Goldman RD. Keratin incorporation into intermediate filament networks is a rapid process. J Cell Biol 1991;113:843-855. [PubMed: 1709167]

73. Mizuno Y, Guyon JR, Okamoto K, Kunkel LM. Synemin expression in brain. Muscle Nerve 2007;36:497-504. [PubMed: 17654553]

74. Morgan KG, Gangopadhyay SS. Invited review: cross-bridge regulation by thin filament-associated proteins. J Appl Physiol 2001;91:953-962. [PubMed: 11457814]

75. Mucke N, Wedig T, Burer A, Marekov LN, Steinert PM, Langowski J, Aebi U, Herrmann H. Molecular and biophysical characterization of assembly-starter units of human vimentin. J Mol Biol 2004;340:97-114. [PubMed: 15184025]

76. Newey SE, Howman EV, Ponting CP, Benson MA, Nawrotzki R, Loh NY, Davies KE, Blake DJ. Syncoilin, a novel member of the intermediate filament superfamily that interacts with alphadystrobrevin in skeletal muscle. J Biol Chem 2001;276:6645-6655. [PubMed: 11053421]

77. Ogden K, Thompson JM, Hickner Z, Huang T, Tang DD, Watts SW. A new signaling paradigm for serotonin: use of Crk-associated substrate in arterial contraction. Am J Physiol Heart Circ Physiol 2006;291:H2857-H2863. [PubMed: 16861698]

78. Ohtakara K, Inada H, Goto H, Taki W, Manser E, Lim L, Izawa I, Inagaki M. p21-activated kinase PAK phosphorylates desmin at sites different from those for Rho-associated kinase. Biochem Biophys Res Commun 2000;272:712-716. [PubMed: 10860820]

79. Park S, Rasmussen H. Carbachol-induced protein phosphorylation changes in bovine tracheal smooth muscle. J Biol Chem 1986;261:15734-15739. [PubMed: 3782086]

80. Parry DA, Strelkov SV, Burkhard P, Aebi U, Herrmann H. Towards a molecular description of intermediate filament structure and assembly. Exp Cell Res 2007;313:2204-2216. [PubMed: 17521629]

81. Paul RJ, Bowman PS, Kolodney MS. Effects of microtubule disruption on force, velocity, stiffness and $[\mathrm{Ca}(2+)](\mathrm{i})$ in porcine coronary arteries. Am J Physiol Heart Circ Physiol 2000;279:H2493H2501. [PubMed: 11045987]

82. Pollard TD. Regulation of actin filament assembly by Arp2/3 complex and formins. Annu Rev Biophys Biomol Struct 2007;36:451-477. [PubMed: 17477841] 
83. Poon E, Howman EV, Newey SE, Davies KE. Association of syncoilin and desmin: linking intermediate filament proteins to the dystrophin-associated protein complex. J Biol Chem 2002;277:3433-3439. [PubMed: 11694502]

84. Quinlan RA, Franke WW. Molecular interactions in intermediate-sized filaments revealed by chemical cross-linking. Heteropolymers of vimentin and glial filament protein in cultured human glioma cells. Eur J Biochem 1983;132:477-484. [PubMed: 6682757]

85. Quintanar JL. Vimentin in cultured chromaffin cells: an immunofluorescent, biochemical and functional study. Cell Physiol Biochem 2000;10:91-98. [PubMed: 10844400]

86. Rokolya A, Singer HA. Inhibition of CaM kinase II activation and force maintenance by KN-93 in arterial smooth muscle. Am J Physiol Cell Physiol 2000;278:C537-C545. [PubMed: 10712242]

87. Runembert I, Queffeulou G, Federici P, Vrtovsnik F, Colucci-Guyon E, Babinet C, Briand P, Trugnan G, Friedlander G, Terzi F. Vimentin affects localization and activity of sodium-glucose cotransporter SGLT1 in membrane rafts. J Cell Sci 2002;115:713-724. [PubMed: 11865027]

88. Sahlgren CM, Mikhailov A, Vaittinen S, Pallari HM, Kalimo H, Pant HC, Eriksson JE. Cdk5 regulates the organization of Nestin and its association with p35. Mol Cell Biol 2003;23:5090-5106. [PubMed: 12832492]

89. Schmid E, Osborn M, Rungger-Brandle E, Gabbiani G, Weber K, Franke WW. Distribution of vimentin and desmin filaments in smooth muscle tissue of mammalian and avian aorta. Exp Cell Res 1982;137:329-340. [PubMed: 7035200]

90. Schmitt-Graeff A, Jing R, Nitschke R, Desmouliere A, Skalli O. Synemin expression is widespread in liver fibrosis and is induced in proliferating and malignant biliary epithelial cells. Hum Pathol 2006;37:1200-1210. [PubMed: 16938526]

91. Schmitz AA, Govek EE, Bottner B, Van Aelst L. Rho GTPases: signaling, migration, and invasion. Exp Cell Res 2000;261:1-12. [PubMed: 11082269]

92. Schweizer J, Langbein L, Rogers MA, Winter H. Hair follicle-specific keratins and their diseases. Exp Cell Res 2007;313:2010-2020. [PubMed: 17428470]

93. Sin WC, Chen XQ, Leung T, Lim L. RhoA-binding kinase alpha translocation is facilitated by the collapse of the vimentin intermediate filament network. Mol Cell Biol 1998;18:6325-6339. [PubMed: 9774649]

94. Sjuve R, Arner A, Li Z, Mies B, Paulin D, Schmittner M, Small JV. Mechanical alterations in smooth muscle from mice lacking desmin. J Muscle Res Cell Motil 1998;19:415-429. [PubMed: 9635284]

95. Small JV. Structure-function relationships in smooth muscle: the missing links. Bioessays 1995;17:785-792. [PubMed: 8763831]

96. Small JV, Rottner K, Kaverina I. Functional design in the actin cytoskeleton. Curr Opin Cell Biol 1999;11:54-60. [PubMed: 10047522]

97. Soellner P, Quinlan RA, Franke WW. Identification of a distinct soluble subunit of an intermediate filament protein: tetrameric vimentin from living cells. Proc Natl Acad Sci U S A 1985;82:79297933. [PubMed: 3865206]

98. Somlyo AP, Somlyo AV. Signal transduction by G-proteins, rho-kinase and protein phosphatase to smooth muscle and non-muscle myosin II. J Physiol 2000;522(Pt 2):177-185. [PubMed: 10639096]

99. Sonnenberg A, Liem RK. Plakins in development and disease. Exp Cell Res 2007;313:2189-2203. [PubMed: 17499243]

100. Starger JM, Brown WE, Goldman AE, Goldman RD. Biochemical and immunological analysis of rapidly purified 10-nm filaments from baby hamster kidney (BHK-21) cells. J Cell Biol 1978;78:93109. [PubMed: 566763]

101. Strelkov SV, Herrmann H, Geisler N, Wedig T, Zimbelmann R, Aebi U, Burkhard P. Conserved segments $1 \mathrm{~A}$ and $2 \mathrm{~B}$ of the intermediate filament dimer: their atomic structures and role in filament assembly. EMBO J 2002;21:1255-1266. [PubMed: 11889032]

102. Takahashi T, Kawahara Y, Taniguchi T, Yokoyama M. Tyrosine phosphorylation and association of p130Cas and c-Crk II by ANG II in vascular smooth muscle cells. Am J Physiol 1998;274:H1059H1065. [PubMed: 9575907]

103. Tang DD, Bai Y, Gunst SJ. Silencing of p21-activated kinase attenuates vimentin phosphorylation on Ser-56 and reorientation of the vimentin network during stimulation of smooth muscle cells by 5-hydroxytryptamine. Biochem J 2005;388:773-783. [PubMed: 15766329] 
104. Tang DD, Gunst SJ. The small GTPase Cdc42 regulates actin polymerization and tension development during contractile stimulation of smooth muscle. J Biol Chem 2004;279:51722_ 51728. [PubMed: 15456777]

105. Tang DD, Tan J. Downregulation of profilin with antisense oligodeoxynucleotides inhibits force development during stimulation of smooth muscle. Am J Physiol Heart Circ Physiol 2003;285:H1528-H1536. [PubMed: 12805028]

106. Tang DD, Tan J. Role of Crk-Associated Substrate in the Regulation of Vascular Smooth Muscle Contraction. Hypertension 2003;42:858-863. [PubMed: 12885796]

107. Tang DD, Wang R. The intermediate filament protein desmin undergoes tyrosine phosphorylation upon contractile activation of airway smooth muscle. Am J Respir Crit Care Med 2007;175:A348.

108. Tang DD, Zhang W, Gunst SJ. The Adapter Protein CrkII Regulates Neuronal Wiskott-Aldrich Syndrome Protein, Actin Polymerization, and Tension Development during Contractile Stimulation of Smooth Muscle. J Biol Chem 2005;280:23380-23389. [PubMed: 15834156]

109. Turner CE, Brown MC, Perrotta JA, Riedy MC, Nikolopoulos SN, McDonald AR, Bagrodia S, Thomas S, Leventhal PS. Paxillin LD4 motif binds PAK and PIX through a novel 95-kD ankyrin repeat, ARF-GAP protein: A role in cytoskeletal remodeling. J Cell Biol 1999;145:851-863. [PubMed: 10330411]

110. Vaittinen S, Lukka R, Sahlgren C, Hurme T, Rantanen J, Lendahl U, Eriksson JE, Kalimo H. The expression of intermediate filament protein nestin as related to vimentin and desmin in regenerating skeletal muscle. J Neuropathol Exp Neurol 2001;60:588-597. [PubMed: 11398835]

111. Valgeirsdottir S, Claesson-Welsh L, Bongcam-Rudloff E, Hellman U, Westermark B, Heldin CH. PDGF induces reorganization of vimentin filaments. J Cell Sci 1998;111:1973-1980. [PubMed: 9645945]

112. Van Eyk JE, Arrell DK, Foster DB, Strauss JD, Heinonen TY, Furmaniak-Kazmierczak E, Cote GP, Mak AS. Different molecular mechanisms for Rho family GTPase-dependent, Ca2+-independent contraction of smooth muscle. J Biol Chem 1998;273:23433-23439. [PubMed: 9722579]

113. Wang R, Li Q, Tang DD. Role of vimentin in smooth muscle force development. Am J Physiol Cell Physiol 2006;291:C483-C489. [PubMed: 16571866]

114. Wang R, Li QF, Anfinogenova Y, Tang DD. Dissociation of Crk-associated substrate from the vimentin network is regulated by $\mathrm{p} 21$-activated kinase on ACh activation of airway smooth muscle. Am J Physiol Lung Cell Mol Physiol 2007;292:L240-L248. [PubMed: 16997882]

115. Wede OK, Lofgren M, Li Z, Paulin D, Arner A. Mechanical function of intermediate filaments in arteries of different size examined using desmin deficient mice. J Physiol 2002;540:941-949. [PubMed: 11986381]

116. Wiche G. Role of plectin in cytoskeleton organization and dynamics. J Cell Sci 1998;111(Pt 17): 2477-2486. [PubMed: 9701547]

117. Wickert U, Mucke N, Wedig T, Muller SA, Aebi U, Herrmann H. Characterization of the in vitro co-assembly process of the intermediate filament proteins vimentin and desmin: mixed polymers at all stages of assembly. Eur J Cell Biol 2005;84:379-391. [PubMed: 15819415]

118. Wilhelmsen K, Litjens SH, Kuikman I, Tshimbalanga N, Janssen H, van dBI, Raymond K, Sonnenberg A. Nesprin-3, a novel outer nuclear membrane protein, associates with the cytoskeletal linker protein plectin. J Cell Biol 2005;171:799-810. [PubMed: 16330710]

119. Windoffer R, Kolsch A, Woll S, Leube RE. Focal adhesions are hotspots for keratin filament precursor formation. J Cell Biol 2006;173:341-348. [PubMed: 16682525]

120. Windoffer R, Leube RE. De novo formation of cytokeratin filament networks originates from the cell cortex in A-431 cells. Cell Motil Cytoskeleton 2001;50:33-44. [PubMed: 11746670]

121. Windoffer R, Leube RE. Imaging of keratin dynamics during the cell cycle and in response to phosphatase inhibition. Methods Cell Biol 2004;78:321-352. [PubMed: 15646624]

122. Windoffer R, Woll S, Strnad P, Leube RE. Identification of novel principles of keratin filament network turnover in living cells. Mol Biol Cell 2004;15:2436-2448. [PubMed: 15004233]

123. Woolfolk EA, Eguchi S, Ohtsu H, Nakashima H, Ueno H, Gerthoffer WT, Motley ED. Angiotensin II-induced activation of $\mathrm{p} 21$-activated kinase 1 requires $\mathrm{Ca} 2+$ and protein kinase $\mathrm{C}\{$ delta $\}$ in vascular smooth muscle cells. Am J Physiol Cell Physiol 2005;289:C1286-C1294. [PubMed: 16033904] 
124. Yamaguchi T, Goto H, Yokoyama T, Sillje H, Hanisch A, Uldschmid A, Takai Y, Oguri T, Nigg EA, Inagaki M. Phosphorylation by Cdk1 induces Plk1-mediated vimentin phosphorylation during mitosis. J Cell Biol 2005;171:431-436. [PubMed: 16260496]

125. Yoon M, Moir RD, Prahlad V, Goldman RD. Motile properties of vimentin intermediate filament networks in living cells. J Cell Biol 1998;143:147-157. [PubMed: 9763427]

126. Zhang D, Jin N, Rhoades RA, Yancey KW, Swartz DR. Influence of microtubules on vascular smooth muscle contraction. J Muscle Res Cell Motil 2000;21:293-300. [PubMed: 10952177]

127. Zhang W, Gunst SJ. Dynamic association between alpha-actinin and beta-integrin regulates contraction of canine tracheal smooth muscle. J Physiol 2006;572:659-676. [PubMed: 16513669]

128. Zhang W, Wu Y, Du L, Tang DD, Gunst SJ. Activation of the Arp2/3 complex by N-WASp is required for actin polymerization and contraction in smooth muscle. Am J Physiol Cell Physiol 2005;288:C1145-C1160. [PubMed: 15625304]

129. Zimek A, Stick R, Weber K. Genes coding for intermediate filament proteins: common features and unexpected differences in the genomes of humans and the teleost fish Fugu rubripes. J Cell Sci 2003;116:2295-2302. [PubMed: 12697841] 

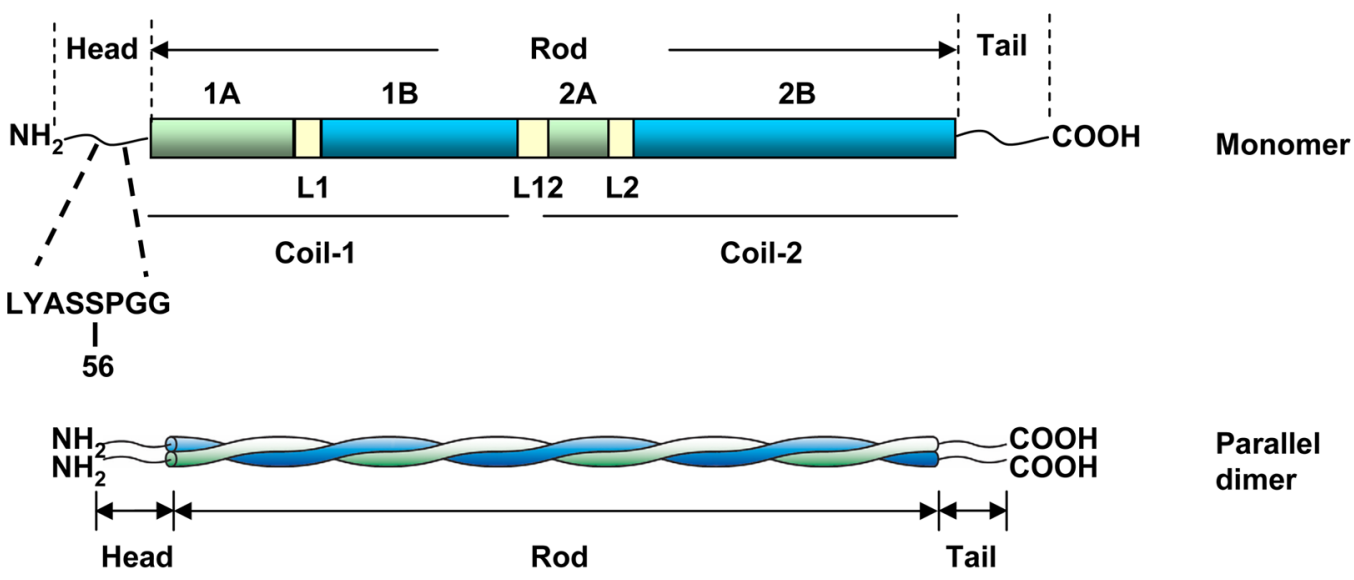

Parallel

dimer

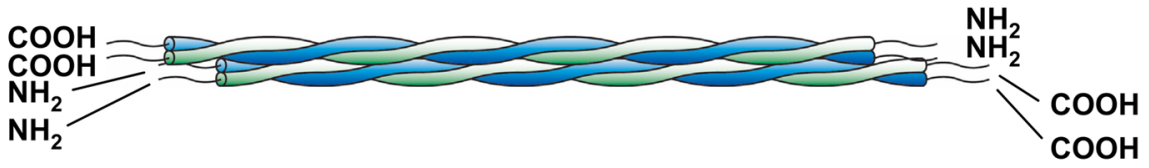

Antiparallel tetramer

Figure 1. Molecular structure of vimentin in smooth muscle

The structure of vimentin consists of a central rod domain, an N-terminal "head" domain, and a C-terminal "tail" domain. These domains are separated by 3 linkers referred to as L1, L12 and L2. Two monomers pair to form a parallel coiled-coil dimer. A pair of dimers associates laterally into an antiparallel tetramer, a soluble subunit for IF assembly in cells. Ser-56 is a major phosphorylation site on vimentin in smooth muscle in response to contractile stimulation. Desmin shares similar molecular structure and assembly processes. 


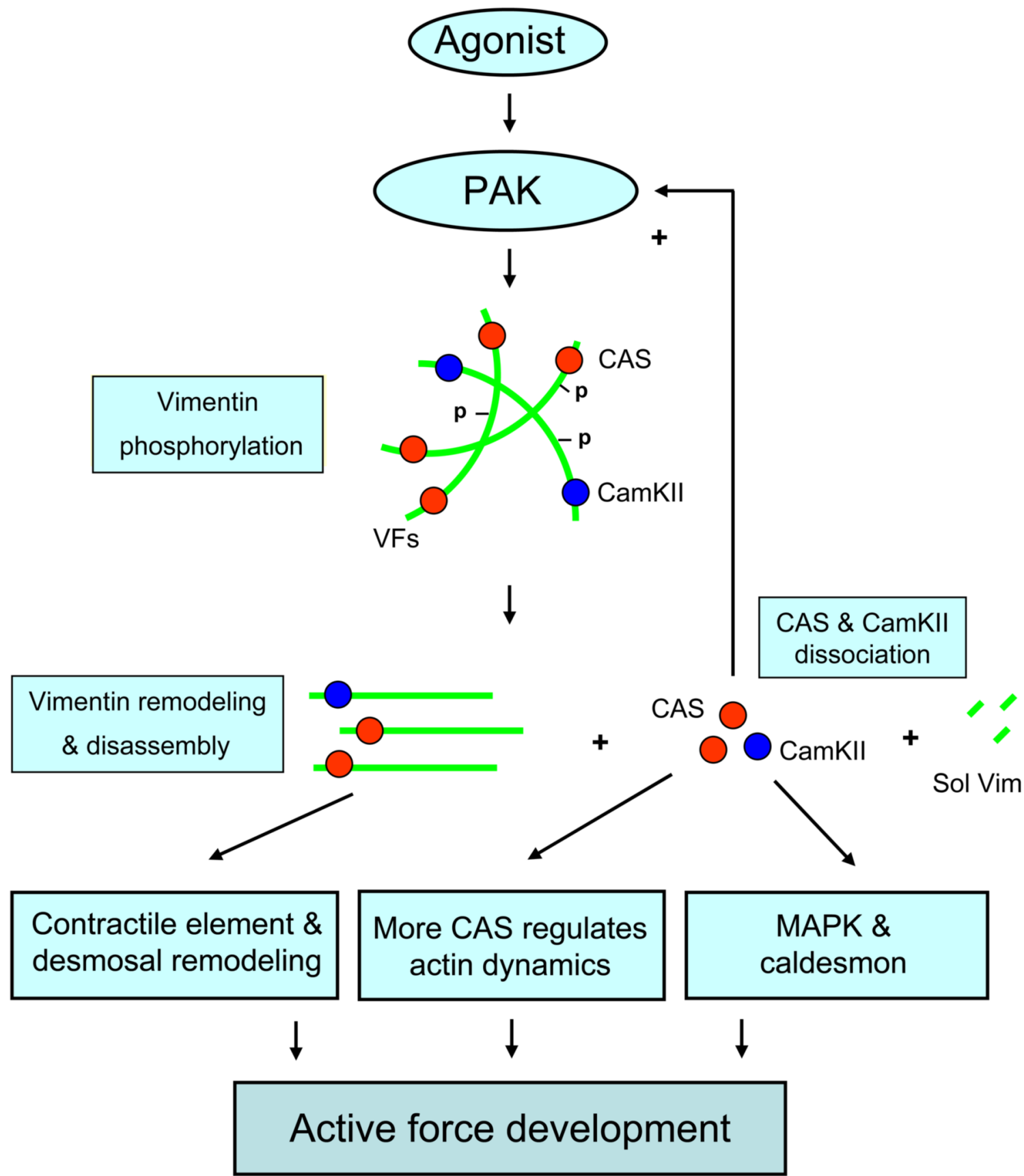

Figure 2. Proposed role and regulation of the vimentin network in smooth muscle Contractile agonists activate the protein kinase PAK, which mediates vimentin phosphorylation at Ser-56. Vimentin phosphorylation may lead to the spatial reorientation and partial disassembly of vimentin filaments. The spatial remodeling of the vimentin cytoskeleton may induce the structural reorganization of contractile elements and/or desmosomes. CAS and CamKII may dissociate from cytoskeletal vimentin. The released CAS may promote cortical actin polymerization in smooth muscle. In addition, the released CAS may render PAK active via the multiprotein complex. The activated CamKII may regulate MAPK that has been shown to mediate caldesmon phosphorylation. These structural and signaling changes in smooth muscle may facilitate active force development in response to contractile stimulation. Green 
line represents vimentin filaments (VFs); red circle, CAS; blue circle, CamKII; Sol Vim, soluble vimentin. 
Table 1

IF proteins and IFAPs in mammalian cells

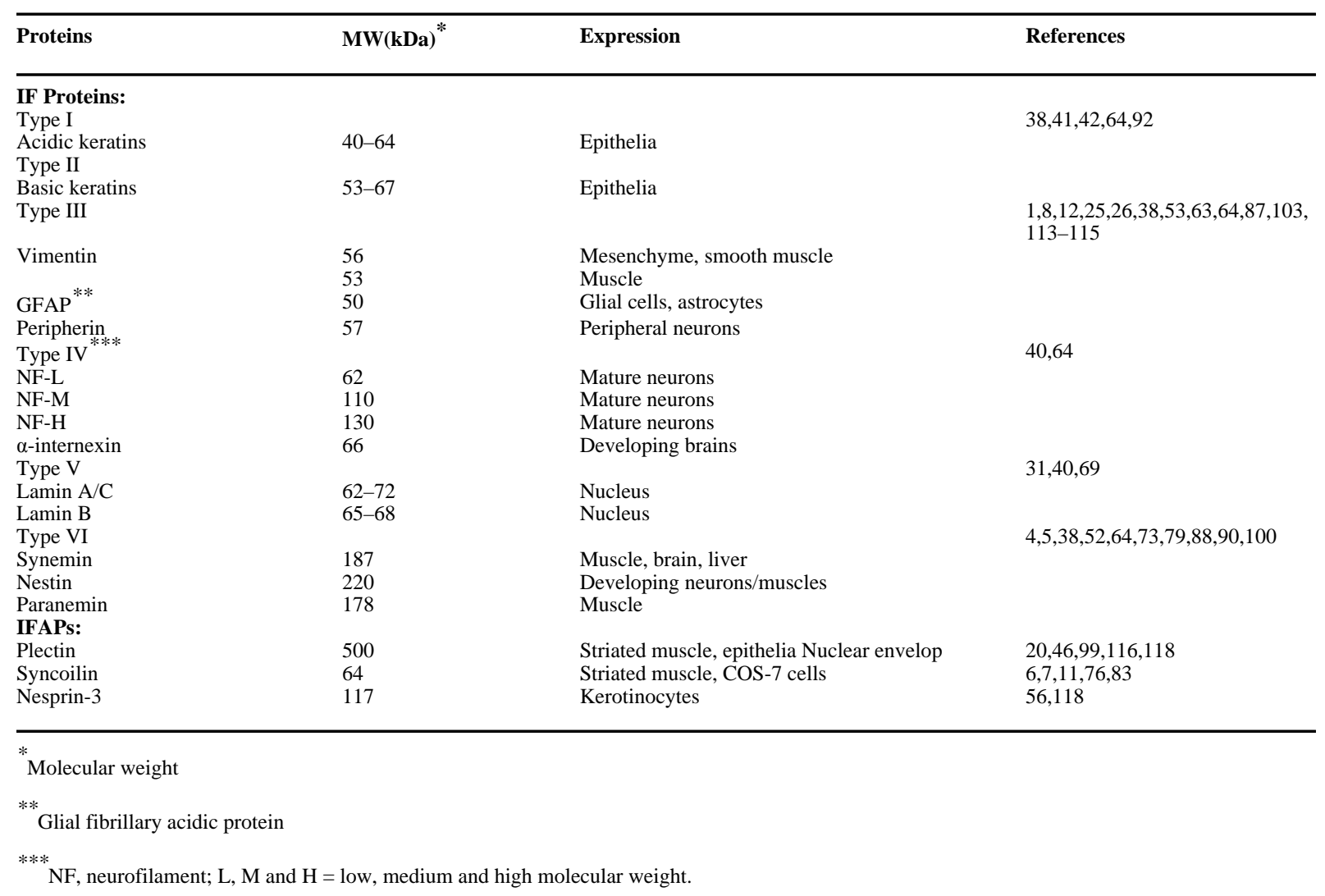

